\title{
Nurmituotannon tehostaminen täydennyskylvöllä
}

\author{
Kari Jokinen ja Mari Ylikojola \\ Kemira GrowHow Oyj, Tutkimuskeskus, PL 2,02271 Espoo, kari.jokinen@kemira-growhow.com
}

\section{Tiivistelmä}

Tällä hetkellä nurmirehuihin perustuvalla kotieläintuotannolla on hyvät taloudelliset kilpailuedellytykset, sillä nurmisato Suomessa on lähellä Keski-Euroopan satotasoa. Nurmilohkot joudutaan kuitenkin uusimaan 3-5 vuoden välein. Tämä onkin merkittävä osa sen tuotantokustannuksista. Täydellisen uusimisen sijasta voidaan nurmen elinkaarta ja satoa lisätä täydennyskylvöllä. Parhaiten täydennyskylvöön soveltuvat lajit ja lajikkeet, joiden alkukehitys on nopea. Täydennyskylvetyn nurmikasvin kilpailukykyvyn kannalta on tärkeää, että kasvi saa heti itämisen jälkeen siemenen ulkopuolisia ravinteita. Aikaisempien tutkimusten mukaan ravinteiden saantia voidaan edistää siemenen ravinnepinnoituksella.

Kemira GrowHow Oyj-yrityksen tuotteisiin kuuluvat iSeed ${ }^{\circledR}$ pinnoitetut siemenet. Uutena iSeed®sovelluskohteena ovat nurmikasvit. Tämän tutkimuksen keskeisenä tavoitteena oli selvittää, voidaanko nurmikasvien alkukehitystä ja sadontuottoa parantaa täydennyskylvöllä ja erityisesti käyttämällä ravinnepinnoitettuja raiheinän ja timotei-nurminadan siemenseoksia. Kokeet tehtiin sekä kasvihuoneessa että kenttäkokein pellolla vuonna 2005.

Tutkimuksen astia- ja kenttäkoetulokset osoittivat, että nurmikasvien siemenen ravinnepinnoitus edistää kasvin kasvua ja tehostaa täydennyskylvöstä saatavaa satoetua. Astiakokeissa kasvin nopean alkukehityksen kannalta parhaimmaksi ravinnepinnoitteeksi osoittautui metyleeniurean (MU) ja monoammoniumfosfaatin (MAP) yhdistelmä. Pinnoitus paransi ravinteiden, erityisesti typen ja fosforin ottoa jo orastumisvaiheessa, mikä oli osittain seurausta juuriston suuremmasta tiheydestä heti itämisen jälkeen. Maan ravinteisuudesta riippumatta kasvin korkeampi ravinnepitoisuus yhdessä tiheämmän juuriston kanssa johti myös parempaan jälkikasvuun.

Ravinnepinnoitetulla siemenellä kylvetyssä kasvustossa oli parempi sadontuottokyky erityisesti toisen kasvujakson aikana pinnoittamattomaan siemeneen verrattuna. Siten siemenen ravinnepinnoitus vahvistaa oraiden kilpailukykyä ja jälkikasvua täydennyskylvetyssä vanhassa nurmessa. Astiakokeisiin perustuen maan ravinnepitoisuuden kohottaminen ei heikennä pinnoitetusta siemenestä saatavaa kasvuetua. Näin ollen pellolla käytetty suositeltu lannoitus edistänee myös iSeed-siemenestä kehittyneen kasvuston sadonmuodostusta. Tämän tutkimuksen vaihtelevissa lannoitus- ja maan ravinneoloissa suoritetut kenttäkokeet tukevat aikaisempia tutkimuksia, joiden mukaan ravinnepinnoitetun nurmisiemenen käyttö on satoedun saavuttamisen suhteen todennäköisempää kuin pinnoittamattoman siemenen käyttö. 


\section{Johdanto}

Nurmien viljelyala Suomessa 2000-luvulla on ollut noin 600000 hehtaaria, joka on kolmannes koko peltoalasta. Tällä hetkellä nurmirehuihin perustuvalla kotieläintuotannolla on hyvät taloudelliset kilpailuedellytykset, sillä nurmisato Suomessa on lähellä Keski-Euroopan satotasoa. Nurmet ovat myös ympäristönhoidon kannalta hyvää pellon käyttöä, koska nurmet käyttävät ravinteita tehokkaasti ja pitävät peltomaan kasvuston peitossa myös syksyllä ja keväällä.

Nurmilohkot joudutaan uusimaan yleensä 3-5 vuoden välein. Ikääntyneiden nurmien ongelmana on usein kasvukunnon voimakas heikkeneminen, jolloin kasvuston tiheys alenee ja rehuarvoltaan heikot rikkakasvit valtaavat peltoalaa. Varsinkin vanhojen timoteinurmien jälkikasvukyky on yleensä heikko (Nissinen 2004).

Nurmen täydellinen uudistaminen ei aina ole taloudellisesti kannattavaa huomioitaessa toisaalta uudistamisen aiheuttamat kustannukset mm. torjunta-aineet, lannoitteet, siemenet, työ- ja konekustannus, mutta toisaalta myös vanhan nurmen kasvukunto. Yleensä nurmen sadon määräytyy kasvuston tiheyden perusteella. Jos nurmessa on riittävästi tuottoisia kasviyksilöitä, voidaan nurmen elinkaarta ja satoa lisätä täydennyskylvöllä (Elsässer 1991). Tällöin uusi siemen kylvetään joko koko alueelle tai vain harventuneisiin kohtiin, jolloin jäljellä olevat elinvoimaiset yksilöt tuottavat satoa edelleenkin ja nuoret yksilöt täyttävät aukkopaikat. Näin ollen onnistunut täydennyskylvö lisää nurmen tiheyttä ja samalla myös tuottavuutta (Knuuttila 2005).

Täydennyskylvö voidaan suorittaa joko keskipakolevittimellä pintakylvönä tai suorakylvökoneella rivikylvönä. Tutkimusten mukaan keskipakolevitys on teknisesti taloudellisin kylvötapa, mutta epätasainen levittyvyys johtuen nurmisiementen keveydestä ja heikko itävyys aiheuttavat perustamisongelmia (Tiley ja Frame 1991, Sheldrick 2000). Siten pintakylvöön verrattuna täydennyskylvö suorakylvökoneella on itämisen ja orastumisen suhteen viljelyvarmempi perustamisvaihtoehto (Bellotti ja Blair 1989, Lewis ja Clements 1999).

Suomessa nurmen täydennyskylvön on todettu onnistuvan paremmin keväällä kuin syksyllä, koska syyskylvetty oras on arka talvituhoille. Sen sijaan keväällä täydennyskylvötulos on hyvä, koska maa on lumen sulamisen jälkeen sopivan kostea ja vanha nurmikasvusto vielä matala helpottaen kylvön teknistä toteutusta (Hakkola 1995, Knuuttila 2005). Täydennyskylvö riittänee keskimäärin joka kolmas vuosi, kun kylvetään monivuotisia nurmikasvilajeja (Knuuttila 2005).

Nurmen täydennyskylvöön sopivat parhaiten alkukehitykseltään nopeat lajit ja lajikkeet (Bellotti ja Blair 1989, Tiley ja Frame 1991, Kunelius ym. 2004). Täydennyskylvetyn nurmikasvin hyvän alkukehityksen kannalta on myös tärkeää, että kasvi saa heti itämisen jälkeen siemenen ulkopuolisia ravinteita (Scott ym. 1985). Tutkimusten mukaan ravinteiden saantia voidaan edistää siemenen ravinnepinnoituksella. Pienisiemeniset lajit kuten nurmikasvit voivat hyödyntää siemenen pinnalla olevia ravinteita jo neljänkin päivän kuluttua kylvöstä (Scott 1998). Ravinnepinnoituksen vaikutus kasvin kasvuun ja kilpailukykyyn riippuvat mm. pinnoituksen tyypistä, kylvettävästä lajista, kylvöajasta, ympäröivästä kasvillisuudesta, maalajista, maan kasvukunnosta ja maan kosteudesta (Scott ym. 1985).

Pinnoitteen koostumuksella ja liukoisuudella on merkittävä vaikutus siemenen itämiseen (Scott 1998). Niukkaliukoisimmat pinnoitteet ovat yleensä turvallisimpia (Scott ja Blair 1988a). Toisaalta pinnoitteen liukoisuuden vähentyessä saattaa ravinteen kasvua edistävä vaikutus heikentyä (Scott ja Blair 1988b). Niukkaliukoiset pinnoitteet ovat yleensä tehokkaampia happamissa kuin emäksisissä maissa (Silcock ja Smith 1982). Hyvin veteen liukenevat pinnoitteet saattavat hidastaa itämistä, mutta useimmiten parantavat eniten oraan kasvua. Vaikka pinnoitus on joissakin tapauksissa viivästyttänyt kasvin itämistä, on pinnoitetusta siemenestä kasvanut kasvusto ollut yleensä tasaisempi ja tuottanut suurimman sadon (Silcock ja Smith 1982, Scott ym. 1985, Scott 1989). Ravinnevaikutuksen lisäksi pinnoitus mahdollistaa kevyiden siementen paremman käsittelyn ja valumisen kylvökoneissa, koska pinnoitus usein lisää siemenen painoa (Scott 1998). Tutkimusten mukaan erityisesti hajalevityksenä kylvetyt ja pinnoitetut siemenet itävät jopa nopeammin kuin pinnoittamattomat siemenet, koska pinnoitus parantaa siemenen kontaktia maan kanssa (Dowling ym. 1971, Scott ym. 1985, Scott 1989, Scott 1998).

Kemira GrowHow Oyj-yrityksen tuotteisiin kuuluvat iSeed® ravinnepinnoitetut siemenet. Pinnoitteena käytetään erilaisia typen, fosforin ja kaliumin lähteitä. Uutena ja potentiaalisena iSeed®- 
sovelluskohteena ovat nurmikasvit. Tämän tutkimuksen keskeisenä tavoitteena oli selvittää, voidaanko nurmikasvien alkukehitystä ja sadontuottoa parantaa täydennyskylvöllä ja erityisesti käyttämällä ravinnepinnoitettuja siemeniä. Kokeet tehtiin sekä kasvihuoneessa että kentällä vuonna 2005.

\section{Aineisto ja menetelmät \\ Astiakokeet}

Siemenen pinnoituskoostumuksen vaikutusta italianraiheinän (Lolium multiflorum L., lajike Fabio) verson ja juuriston alkukehitykseen tutkittiin kasvihuoneessa. Koejäsenet olivat pinnoittamattoman siemen ja kolme metyleeniurealla (15\% N MU) pinnoitettua siementä: MU yksin, MU yhdessä monoammoniumfosfaatin (MU+ 4 \% P MAP) tai monokaliumfosfaatin (MU+ 4 \% P MKP) kanssa. Verson kehitystä tutkittiin astiakokeella ja juuriston kehitystä petrimaljakokeella.

Toisessa astiakokeessa tutkittiin maaperän ravinteisuuden vaikutusta pinnoittamattomasta ja pinnoitetusta (5 \% N MU + 4 \% P MAP) siemenestä kehittyvän italianraiheinän (Lolium multiflorum L., lajike Fabio) ja nurminadan (Festuca pratensis Huds., lajike Ilmari) alkukehitykseen. Maaperän ravinteisuuserot aikaansaatiin sekoittamalla täysin vesiliukoista lannoitetta (Puutarhan Kesä 16N-9P-22K, Kemira GrowHow Oyj, Helsinki, Suomi) homogeenisesti kasvualustaan neljänä eri pitoisuutena: 0, 20, 60 ja 180 $\mathrm{mg} \mathrm{N} / \mathrm{kg}$ maata.

Astiakokeissa käytettiin 3,5 1 muovisia astioita ja 3,5 kg peltomaata/astia (mHHt, $\mathrm{pH}$ 7,5 ja savespitoisuus 9,8\%). Perustamisvaiheessa maan kosteus oli $18 \%$. Kylvötiheys kaikissa koejäsenissä määritettiin niin, että kylvömäärä vastasi $0.75 \mathrm{~g}$ pinnoittamattomia siemeniä per astia. Kylvösyvyys oli $0,5 \mathrm{~cm}$. Astioita kasteltiin päivittäin deioinisoidulla vedellä siten, että kosteus oli $18 \%$. Kasvatuslämpötila oli $20^{\circ} \mathrm{C}$ $(18 \mathrm{~h}) / 16^{\circ} \mathrm{C}(6 \mathrm{~h})$. Valon intensiteetin pudotessa alle $125 \mu \mathrm{mol} / \mathrm{m}^{2} / \mathrm{s}$ käytettiin lisävalona elohopeakorkeapainelamppuja (OSRAM Valox $400 \mathrm{~W}$, NAV-T SUPER, SON-T PLUS, Iso-Britannia). Kerranteiden lukumäärä oli viisi.

Kasvustojen alkukehitystä ja jälkikasvukykyä seurattiin kuivapainon muutoksena (niitot kolmen, viiden ja kahdeksan viikon kuluttua kylvöstä). Kahden senttimetrin korkeudelta niitetty kasvimateriaali kuivattiin kaksi vuorokautta lämpökaapissa $\left(+60^{\circ} \mathrm{C}\right)$. Kasvimateriaali punnittiin ja jauhettiin. Näytteistä määritettiin typpipitoisuus alkuaineanalysaattorilla (LECO CN-2000, Cn-2MCA 1, USA) ja muiden alkuaineiden pitoisuudet röntgenfluoresenssispektrometrillä (XRF, Thermo ARL, Advant 'XP, USA).

Juuriston kehityskokeessa maalla täytettyihin kaksireikäisiin petrimaljoihin $(\varnothing 14 \mathrm{~cm})$ laitettiin kaksi italianraiheinän siementä reikää kohden. Maan kosteus $18 \%$. Kylvön jälkeen maljat suljettiin läpinäkyvällä kannella, jonka läpi mitattiin pääjuuren pituuskasvu ja laskettiin sivujuurten määrää. Kussakin koejäsenessä oli kuusi rinnakkaismaljaa.

Tuloksista laskettiin keskiarvo ja keskiarvon keskivirhe (se).

\section{Kenttäkokeet}

Täydennyskylvön vaikutusta nurmen sadontuottoon tutkittiin kenttäkokein neljällä maatilalla eripuolilla Suomea vuonna 2005 (kts. koepaikat osiosta tulokset). Koejäsenet olivat täydennyskylvämätön, iSeedkäsitelty ja pinnoittamaton siemen. Kylvössä käytettiin joko italianraiheinää (Lolium multiflorum L., lajike Fabio) tai siemenseosta, jossa oli 75 paino-\% timoteitä (Phleum pratense L., lajike Tuure) ja 25 paino-\% nurminataa (Festuca pratensis Huds., lajike Ilmari). iSeed-käsittely pinnoitettiin metyleeniurean (5\% N MU) ja monoammoniumfosfaatin (4\% P MAP) seoksella. Pinnoitteessa oli mukana myös bentoniittilisäainetta.

Täydennyskylvö tehtiin nurmilohkoille, jotka olivat 2-3 vuoden ikäisiä timotein ja nurminadan seoskasvustoja. Kylvö suoritettiin suorakylvökoneella noin 1-2 senttimetrin syvyyteen toukokuun alkupuolella. Koeruutujen leveys oli kylvökoneesta riippuen 3-4 m ja pituus 10 metriä. Kunkin tilan kokeessa oli kaksi kerrannetta. Pinnoittamattoman siemenen kylvömäärä oli $10 \mathrm{~kg} / \mathrm{ha}$ ja iSeed-pinnoitetun $20 \mathrm{~kg} / \mathrm{ha}$ johtuen päällystyksen aiheuttamasta painon kaksinkertaistumisesta. Koealueet lannoitettiin kunkin tilan käytännön mukaan.

Kasvukauden aikana koeruutujen kasvustojen sadontuottoa seurattiin ennen niittoa tai laidunnusta. Kustakin koeruudusta valittiin satunnaisesti kaksi aluetta $\left(2^{*} 0,25 \mathrm{~m}^{2}\right)$, jotka leikattiin kahden senttimetrin korkeudelta maan pinnasta. Näyte punnittiin välittömästi ja siitä teetettiin Valion Artturi-rehuanalyysi: 
kuiva-aine, neutraalidetergenttikuitu (NDF), D-arvo (sulavan orgaanisen aineen määrä rehun kuivaaineessa), raakavalkuainen, Ry-arvo, korvausluku, OIV (ohutsuolessa imeytyvä valkuainen) ja PVT (pötsin valkuaistase).

Tuorepainot ja rehuanalyysien tulokset analysoitiin kaksisuuntaisella varianssianalyysillä, jolloin selittävinä muuttujina olivat tila ja käsittely.

\section{Tulokset ja tulosten tarkastelu}

Pinnoituksen ravinnekoostumuksen vaikutus raiheinän kasvuun ja ravinteiden ottoon

Astiakokeessa testatut siemenen ravinnepinnoitukset edistivät raiheinän verson alkukehitystä pinnoittamattomaan käsittelyyn verrattuna (kuva 1). Voimakkaimmin kehittyivät kasvit, joiden siemenet oli pinnoi-
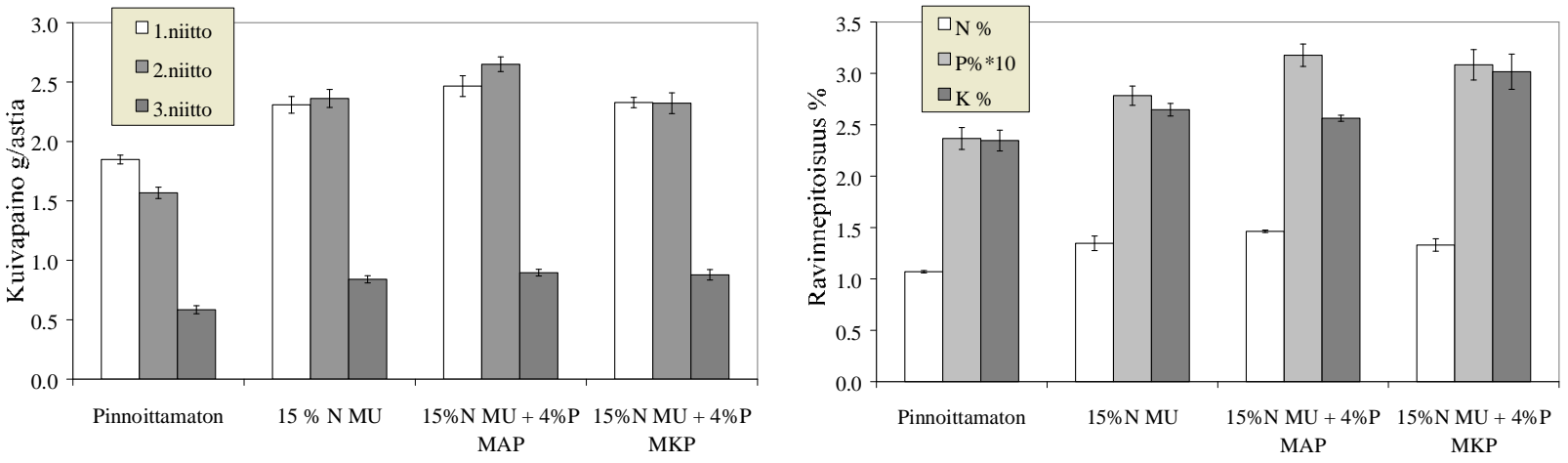

Kuva 1. Siemenen pinnoitekoostumuksen vaikutus raiheinän kuivapainoon (vasen) ja verson ensimmäisen niiton ravinnepitoisuuteen (oikea).

tettu metyleeniurean (MU) ja monoammoniumfosfaatin (MAP) seoksella. Pinnoitus kohotti myös kasvien ravinnepitoisuutta (kuva 1) ja ravinteiden kokonaisottoa. Korkein typpi- ja fosforipitoisuus oli MU+MAP pinnoitetuissa kasveissa. Sen sijaan monokaliumfosfaatti (MKP) yhdessä metyleeniureapinnoituksen kanssa kohotti kasvin kaliumpitoisuuden korkeimmaksi.
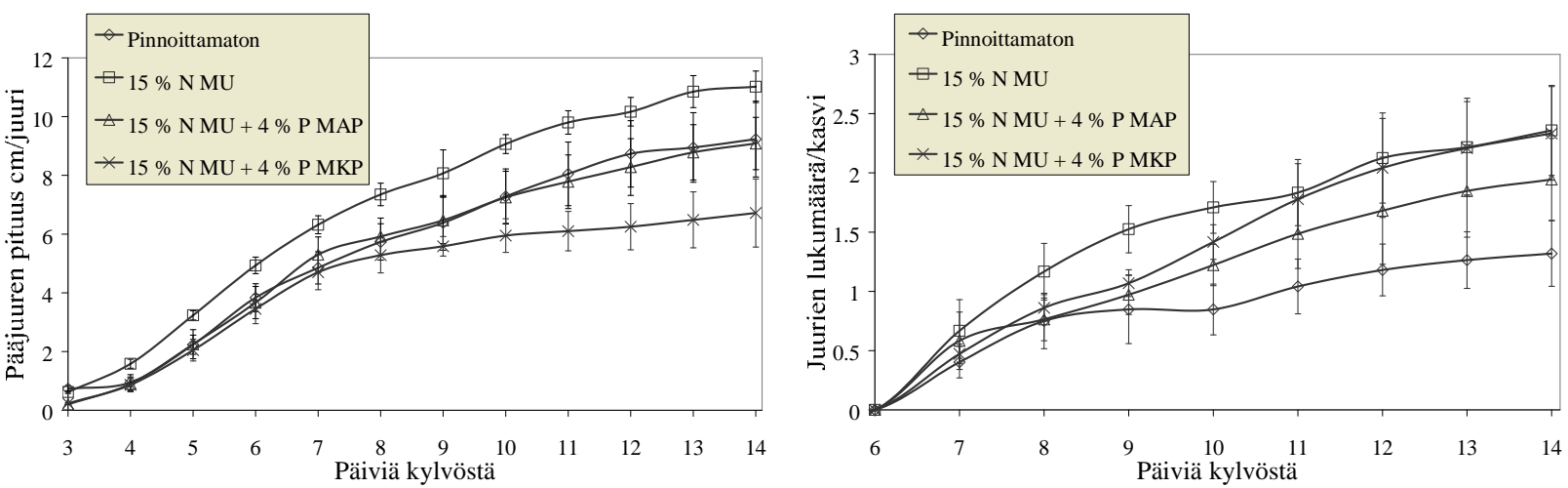

Kuva 2. Siemenen pinnoitekoostumuksen vaikutus raiheinän pääjuuren pituuskasvuun (vasen) ja juurten lukumäärään (oikea) yksilökehityksen alkuvaiheessa.

Siemenen pinnoitus ravinteilla sääteli sekä pääjuuren pituuskasvua että juuriston arkkitehtuuria. Nopein pääjuuren kasvu oli siemenistä, jotka oli pinnoitettu yksinomaan MU:lla, ja hitain siemenistä, joiden pinnoitus koostui MU:n lisäksi MKP:sta (kuva 2). Kaikki siemenen pinnoitteet edistivät jälkijuurten muodostusta pinnoittamattomaan verrattuna (kuva 2). Kaikkein eniten juuriston tiheyttä yksilökehityksen alkuvaiheessa lisäsi pinnoitus joko yksinomaan MU:lla tai yhdessä MKP:n kanssa. 


\section{Maan ravinnetason vaikutus iSeed-pinnoitetun ja pinnoittamattoman nurmikasvin alkukehitykseen}

Mitä ravinnerikkaampi oli maa, sitä nopeampi oli sekä raiheinän että nurminadan alkukehitys ja jälkikasvu (Taulukko 1). Raiheinän versoston alkukehitys oli keskimäärin voimakkaampaa kuin nurminadan.

Taulukko 1. Maan ravinnetason ja siemenen pinnoituksen vaikutus raiheinän ja nurminadan kuivapainoon (g/astia) (se=keskiarvon keskivirhe, rel=iSeed kuivapaino/pinnoittamaton kuivapaino*100).

\begin{tabular}{|l|lll|lll|lll|}
\hline \multirow{2}{*}{$\begin{array}{c}\text { Pinnoitus ja ravinnetaso } \\
\text { mg N/kg maata }\end{array}$} & \multicolumn{3}{|c|}{ Raiheinä } \\
\cline { 2 - 10 }$y$ & g/astia & se & rel & g/astia & se & rel & g/astia & se & rel \\
\hline iSeed 0 & 6.32 & 0.05 & 102 & 1.07 & 0.02 & 109 & 0.76 & 0.02 & 115 \\
iSeed 20 & 6.69 & 0.05 & 99 & 1.53 & 0.02 & 101 & 0.97 & 0.03 & 120 \\
iSeed 60 & 7.25 & 0.08 & 100 & 2.51 & 0.12 & 118 & 1.65 & 0.04 & 106 \\
iSeed 180 & 7.75 & 0.16 & 96 & 4.49 & 0.33 & 130 & 2.77 & 0.09 & 118 \\
Pinnoittamaton 0 & 6.20 & 0.03 & & 0.98 & 0.03 & & 0.66 & 0.03 & \\
Pinnoittamaton 20 & 6.74 & 0.06 & & 1.51 & 0.03 & & 0.81 & 0.02 & \\
Pinnoittamaton 60 & 7.28 & 0.02 & & 2.13 & 0.06 & & 1.56 & 0.03 & \\
Pinnoittamaton 180 & 8.07 & 0.08 & & 3.46 & 0.22 & & 2.35 & 0.04 \\
\hline
\end{tabular}

\begin{tabular}{|l|lll|lll|lll|}
\hline \multirow{2}{*}{$\begin{array}{c}\text { Pinnoitus ja ravinnetaso } \\
\text { mg N/kg maata }\end{array}$} & \multicolumn{3}{|c|}{ 1.niitto } & \multicolumn{3}{|c|}{ 2.niitto } & \multicolumn{3}{c|}{ 3.niitto } \\
\cline { 2 - 10 }$y$ & g/astia & se & rel & g/astia & se & rel & g/astia & se & rel \\
\hline iSeed 0 & 1.96 & 0.04 & 108 & 1.04 & 0.03 & 125 & 0.41 & 0.02 & 116 \\
iSeed 20 & 2.91 & 0.02 & 103 & 1.85 & 0.04 & 116 & 0.64 & 0.02 & 136 \\
iSeed 60 & 3.63 & 0.07 & 94 & 3.13 & 0.11 & 115 & 1.14 & 0.04 & 134 \\
iSeed 180 & 3.77 & 0.09 & 95 & 6.10 & 0.54 & 112 & 3.30 & 0.51 & 119 \\
Pinnoittamaton 0 & 1.82 & 0.02 & & 0.83 & 0.04 & & 0.36 & 0.02 & \\
Pinnoittamaton 20 & 2.84 & 0.04 & & 1.60 & 0.04 & & 0.47 & 0.02 & \\
Pinnoittamaton 60 & 3.86 & 0.03 & & 2.72 & 0.05 & & 0.85 & 0.02 & \\
Pinnoittamaton 180 & 3.97 & 0.10 & 5.43 & 0.54 & & 2.78 & 0.32 & \\
\hline
\end{tabular}

Molemmilla lajeilla siemenen iSeed-pinnoitus edisti lajin jälkikasvua erityisesti toisen ja kolmannen kehitysjakson aikana pinnoittamattomaan siemeneen verrattuna. iSeed-pinnoituksen aiheuttama kasvuetu toteutui kaikilla ravinnetasoilla, mutta niukkaravinteisessa maassa lajeista nurminata hyötyi suhteellisesti enemmän pinnoituksesta kuin raiheinä.

Ensimmäisen kasvujakson lopussa sekä raiheinän että nurminadan iSeed-pinnoitus kohotti kasvustojen typpipitoisuutta keskimäärin $6 \%$ pinnoittamattomaan verrattuna. Myös kasvuston rikkipitoisuus lisääntyi (7-10 \%). Näiden ravinteiden pitoisuuden lisäys oli melko riippumaton maan ravinnepitoisuudesta. Sen sijaan maaperän ravinnepitoisuuden ollessa $60 \mathrm{mg}$ N/kg maata oli iSeed-pinnoituksen positiivinen vaikutus kasvustojen fosforipitoisuuteen suurin (6-10\%). Siten iSeed-pinnoitus edisti myös kasvustojen sekä typen, fosforin että rikin kokonaisottoa. Muiden mitattujen ravinteiden (kalium, kalsium ja magnesium) pitoisuuksiin pinnoituksella ei ollut merkittävää vaikutusta. Toisen kasvujakson lopussa kasvustojen ravinnepitoisuudet olivat melko riippumattomia siemenen käsittelystä. 


\section{Raiheinän ja timotei-nurminata-seoksen vaikutus täydennyskylvetyn nurmen sadontuottoon}

Ensimmäinen sato korjattiin kesäkuun puolivälissä. Täydennyskylvetyt kasvit olivat tällöin pieniä, noin 10 - $15 \mathrm{~cm}$ korkeita ja 1 - 2 lehtiasteella. Orastuvuudessa ei havaittu eroja iSeed-pinnoitetun ja pinnoittamattoman käsittelyn välillä. Raiheinäkokeen ensimmäisen niiton keskimääräinen tuoresato oli $16800 \mathrm{~kg} / \mathrm{ha} \mathrm{ja}$ timotei-nurminata-seoksen $15100 \mathrm{~kg} / \mathrm{ha}$. Eri käsittelyiden välillä (täydennyskylvämätön, iSeed ja pinnoittamaton) ei ollut merkitseviä satoeroja.

Toinen sato korjattiin elokuun alussa, jolloin täydennyskylvetyt kasvit olivat tunnistettavissa. Sekä raiheinä- että timotei-nurminata-seoskokeen täydennyskylvämättömän kasvuston tuoresato oli keskimäärin $12200 \mathrm{~kg} / \mathrm{ha}$. Molemmissa kokeissa iSeed-käsitelty siemen tuotti keskimäärin suurimman tuoresadon pinnoittamattomalla siemenellä kylvettyyn ja täydennyskylvämättömään kasvustoon verrattuna (taulukko 2) (raiheinä iSeed vs. pinnoittamaton $p<0,05$; timotei-nurminata iSeed vs. pinnoittamaton $p<0,05$ ). Täydennyskylvö pinnoittamattomalla siemenellä ei keskimäärin parantanut nurmen toisen niiton tuottoa. Vaikka tilojen väliset erot olivat tilastollisesti merkitseviä $(p<0,05)$, oli iSeed-siemenellä täydennyskylvetty kasvusto useimmissa tapauksissa (5/6) satoisin (taulukko 2).

Taulukko 2. Ravinnepinnoitetulla (iSeed) ja pinnoittamattomalla siemenellä täydennyskylvetyn raiheinän ja timoteinurminata-seoksen vaikutus vanhan nurmen toisen niiton tuoresatoon $(\mathrm{kg} / \mathrm{ha})$ eri koepaikoilla.

\begin{tabular}{|l|lrr|lll|}
\hline Käsittely & \multicolumn{3}{|c|}{ Raiheinä } & \multicolumn{3}{c|}{ Timotei-Nurminata } \\
& Paikka & rel & Sato & Paikka & rel & Sato \\
\hline Ei täydennyskylvöa & Kotkaniemi & 100 & 20900 & Kotkaniemi & 100 & 21760 \\
iSeed & & 124 & 25930 & & 104 & 22550 \\
Pinnoittamaton & & 102 & 21420 & & 90 & 19500 \\
\hline Ei täydennyskylvöa & Kärsämäki & 100 & 8710 & Kärsämäki & 100 & 8010 \\
iSeed & & 126 & 10950 & & 107 & 8590 \\
Pinnoittamaton & & 114 & 9940 & & 106 & 8480 \\
\hline Ei täydennyskylvöa & Pyhäsalmi & 100 & 11210 & Saarijärvi & 100 & 9550 \\
iSeed & & 127 & 14290 & & 135 & 12890 \\
Pinnoittamaton & & 78 & 8695 & & 105 & 10060 \\
\hline Ei täydennyskylvöa & Vampula & 100 & 8340 & Vampula & 100 & 9640 \\
iSeed & & 132 & 11040 & & 127 & 12280 \\
Pinnoittamaton & & 136 & 11330 & & 104 & 10060 \\
\hline Ei täydennyskylvöa & Keskiarvo & 100 & 12290 & Keskiarvo & 100 & 12240 \\
iSeed & & 127 & 15553 & & 115 & 14078 \\
Pinnoittamaton & & 105 & 12846 & & 98 & 12025 \\
\hline
\end{tabular}

Kolmas sato korjattiin ainoastaan osalta tiloista syyskuun lopulla (keskimääräinen tuoresato: raiheinäkoe $4464 \mathrm{~kg} / \mathrm{ha}$ ja timotei-nurminataseoskoe $4917 \mathrm{~kg} / \mathrm{ha}$ ). Molemmissa kokeissa täydennyskylvettyjen kasvustojen keskimääräinen sato oli noin 20-30 \% suurempi kuin täydennyskylvämättömän kasvuston sato (raiheinäkoe $\mathrm{p}<0,05$ ja timotei-nurminata-seoskoe $\mathrm{p}>0,10$ ). Kolmannessa niitossa iSeed-kasvusto ei ollut yksiselitteisesti tuottoisampi kuin pinnoittamattomasta siemenestä kehittynyt kasvusto.

Kasvuston täydennyskylvö ei vaikuttanut yksiselitteisesti eikä tilastollisesti merkitsevästi rehusadon laatuun.

\section{Johtopäätökset}

Tämän tutkimuksen astia- ja kenttäkoetulokset osoittivat, että nurmikasvien siemenen ravinnepinnoitus (iSeed®) edistää kasvin kasvua ja tehostaa täydennyskylvöstä saatavaa satoetua. Astiakokeissa kaikki testatut siemenen ravinnepinnoitukset edistivät yksilönkehitystä pinnoittamattomaan verrattuna. Kasvin nopean alkukehityksen kannalta parhaimmaksi ravinnepinnoitteeksi osoittautui metyleeniurean (MU) ja monoammoniumfosfaatin (MAP) yhdistelmä. Ravinnepinnoitus paransi kasvin ravinteiden, erityisesti ty- 
pen ja fosforin ottoa jo orastumisvaiheessa, mikä oli osittain seurausta juuriston suuremmasta tiheydestä heti itämisen jälkeen. Kasvin korkeampi ravinnepitoisuus yhdessä tiheämmän juuriston kanssa johti verson voimakkaampaan alkukehitykseen ja parempaan jälkikasvuun maan ravinteisuudesta riippumatta.

Kenttäkokeissa täydennyskylvö ei johtanut satoetuun ensimmäisen kasvujakson aikana. Mutta huomioitaessa kenttäkokeiden kolmannen niiton vaikutus kokonaissatoon, paransi täydennyskylvö vanhan nurmen sadontuottoa kylvämättömään verrattuna. Ravinnepinnoitetulla siemenellä kylvetty kasvusto oli satoisampi erityisesti toisen kasvujakson aikana kuin pinnoittamattomalla kylvetty. Siten siemenen ravinnepinnoitus vahvisti oraiden kilpailukykyä ja jälkikasvua täydennyskylvetyssä vanhassa nurmessa, kun vanha kasvusto oli niitetty varjostamasta. Vaikka kenttäkokeissa ei systemaattisesti selvitetty lannoituksen vaikutusta täydennyskylvön satoetuun, astiakokeiden tulokset kuitenkin osoittivat, että maan ravinnepitoisuuden kohottaminen ei heikennä pinnoitetusta siemenestä saatavaa kasvuetua pinnoittamattomaan verrattuna. Näin ollen pellolla käytetty suositeltu lannoitus edistänee myös iSeed-siemenestä kehittyneen kasvuston sadonmuodostusta. Tämän tutkimuksen vaihtelevissa lannoitus- ja maan ravinneoloissa suoritetut kenttäkokeet tukevat aikaisempia tutkimuksia, joiden mukaan ravinnepinnoitetun nurmisiemenen käyttö täydennyskylvössä on satoedun saavuttamisen suhteen todennäköisempää kuin pinnoittamattoman siemenen käyttö.

Täydennyskylvön satoedun suuruus vaihteli peltolohkoittain. Jatkotutkimuksissa tulisikin selvittää, miten paljon vanhan kasvuston tiheys ja kasvukunto vaikuttavat satoedun suuruuteen ja taloudelliseen hyötyyn. Tiheys- ja kasvukuntomittari helpottaisi päätöksentekoa käytännössä, kun täydennyskylvön tarpeellisuutta arvioidaan.

\section{Kirjallisuus}

Bellotti, W. D. \& Blair, G. J. 1989. The influence of sowing method on perennial grass establishment. III. Survival and growth of emerged seedlings. Aust. J. Agric. Res. 40: 323-331.

Dowling, P. M., Clements, R. J. ja McWilliam, J. R. 1971. Establishment and survival of pasture species from seeds sown on the soil surface. Aust. J. Agric. 22: 61-74.

Elsässer, M. 1991. Possibilities and economic evaluation of sward management by methods for grassland improvment. Grassland Renovation and Weed Control in Europe. Konferenssijulkaisu. BAL Gumpenstein. s. 11-14.

Knuuttila, J. 2005. Suorakylvö löysi todellisen leipälajinsa. Koneviesti 11: 42-44.

Kunelius, H. T., McRae, K. B., Dürr, G. H. \& Fillmore, S. A. E. 2004. Management of Italian and perennial ryegrasses for seed and forage production in crop rotations. J. Agr. Crop Sci. 190: 130-137.

Lewis, G. C. \& Clements, R. O. 1999. Effect of combined insecticide and fungicide treatments on newly sown swards of Italian and perennial ryegrass using two methods of sowing, two rates of seed and $\mathrm{N}$ fertilizer, with and without herbicide. Grass For. Sci. 54: 155-162.

Nissinen O. 2004. Nuori nurmi tuottaa eniten. Koetoiminta ja Käytäntö 61:13

Scott, J. M., Mitchell, C. J. M. ja Blair, G. J. 1985. The effect of nutrient seed coating on the emergence and early growth of perennial ryegrass. Aust. J. Agric. Res. 36: 221-231.

Scott, J. M. \& Blair, G. J. 1988a. Phosphorus seed coatings for pasture species. I. Effect of source and rate of phosphorus on emergence and early growth of phalaris (Phalaris aquatica L.) and Lucerne (Medicago sativa L.). Aust. J. Agric. Res. 39: 437-445.

Scott, J. M. \& Blair, G. J. 1988b. Phosphorus seed coatings for pasture species. II. Comparison of effectiveness of phosphorus applied as seed coatings, drilled or broadcast applications in promoting early growth of phalaris (Phalaris aquatica L.) and Lucerne (Medicago sativa L.). Aust. J. Agric.Res. 39: 447-456.

Scott, J. M. 1989. Seed coatings and treatments and their effects on plant establishment. Adv. Agron. 42: 43-83.

Scott, J. M. 1998. Delivering Fertilizers through seed coatings. Teoksessa: Rengel, Z. (toim.). Nutrient use in crop production. The Haworth Press, Inc. New York. s. 197-220.

Sheldrick, R. D. 2000. Sward establishment and renovation. Teoksessa: Hopkins, A. (toim.). Grass, Its Production and Utilization. 3. painos. Cornwall, Blackwell Science Ltd. s. 13-30.

Silcock, R. D. ja Smith, F. T. 1982. Seed coating and localized application of phosphate for improving seedling growth of grasses on acid, sandy red earths. Aust. J. Agric. Res. 33: 785-802.

Tiley, G. E. D. \& Frame, J. 1991. Improvement of upland permanent pastures and lowland swards by surface sowing methods. Grassland Renovation and Weed Control in Europe. Konferenssijulkaisu. BAL Gumpenstein. s. 89-94. 